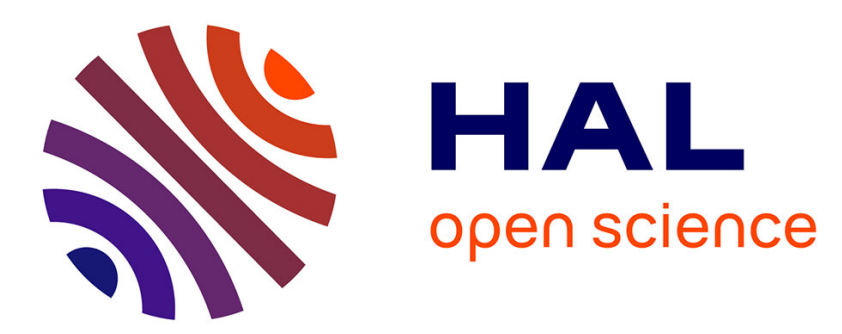

\title{
Paramagnetism and specific heat of the graphite lamellar compound $\mathrm{C} 6 \mathrm{Li}$
}

P. Delhaes, J.C. Rouillon, J.P. Manceau, D. Guerard, A. Herold

\section{To cite this version:}

P. Delhaes, J.C. Rouillon, J.P. Manceau, D. Guerard, A. Herold. Paramagnetism and specific heat of the graphite lamellar compound C6Li. Journal de Physique Lettres, 1976, 37 (5), pp.127-129. 10.1051/jphyslet:01976003705012700 . jpa-00231254

\section{HAL Id: jpa-00231254 https://hal.science/jpa-00231254}

Submitted on 1 Jan 1976

HAL is a multi-disciplinary open access archive for the deposit and dissemination of scientific research documents, whether they are published or not. The documents may come from teaching and research institutions in France or abroad, or from public or private research centers.
L'archive ouverte pluridisciplinaire HAL, est destinée au dépôt et à la diffusion de documents scientifiques de niveau recherche, publiés ou non, émanant des établissements d'enseignement et de recherche français ou étrangers, des laboratoires publics ou privés. 


\title{
PARAMAGNETISM AND SPECIFIC HEAT OF THE GRAPHITE LAMELLAR COMPOUND $\mathrm{C}_{6} \mathrm{Li}$
}

\author{
P. DELHAES, J. C. ROUILlON, J. P. MANCEAU
}

Centre de Recherches Paul-Pascal, C.N.R.S., Domaine Universitaire, 33405 Talence, France

et

\author{
D. GUERARD, A. HEROLD
}

Laboratoire de Chimie Appliquée, Université de Nancy I, Nancy, France

(Reçu le 6 février 1976, révisé le 1er mars 1976, accepté le 5 mars 1976)

\begin{abstract}
Résumé. - Les composés lamellaires du graphite $\mathrm{C}_{8} \mathrm{M}(\mathrm{M}=\mathrm{K}, \mathrm{Rb}, \mathrm{Cs})$ sont bien connus ; l'apparition de la supraconductivité au-dessous de $1 \mathrm{~K}$ a été signalée [1] discutée [2] mais pas confirmée [3]. Un composé lamellaire avec du lithium a déjà été étudié [4] mais préparé avec une stœchiométrie bien définie récemment $\left(\mathrm{C}_{6} \mathrm{Li}\right)$ [5]. Pour comprendre la structure électronique de ce composé métallique et examiner la possibilité d'apparition d'un état supraconducteur, les propriétés physiques à l'équilibre : magnétisme statique, R.P.E., et chaleur spécifique ont été étudiées jusqu'à 1,5 K.

Abstract. - The alkali-metal graphite lamellar compounds $\mathrm{C}_{8} \mathrm{M}$ with $\mathrm{M}=\mathrm{K}, \mathrm{Rb}, \mathrm{Cs}$ are well known. In the first stage intercalation compounds the occurence of superconductivity, below $1 \mathrm{~K}$, has been reported [1] and discussed [2] but not confirmed [3]. A lamellar compound with lithium was studied a long time ago [4] but only recently was it synthesized with a well-defined stoichiometry $\left(\mathrm{C}_{6} \mathrm{Li}\right)$ [5]. In order to understand the electronic structure of this metallic compound and to examine the possible existence of superconductivity the physical properties at thermal equilibrium, namely static susceptibility, E.P.R., and specific heat have been examined at temperatures down to $1.5 \mathrm{~K}$.
\end{abstract}

1. Samples preparation. - The first stage intercalation compound $\mathrm{C}_{6} \mathrm{Li}$ has been prepared by reaction at room temperature of a mixture of graphite and lithium powders under high pressures (1520 kbars) [5]. This compound, which is a brass-like colour, must be conserved under inert atmosphere after heat-treatment at $200^{\circ} \mathrm{C}$ because it is very reactive with air.

Crystallographic study shows that the compound is made of alternate layers of graphite and lithium; the hexagonal unit cell belongs to the $\mathrm{P} 6 / \mathrm{mmm}$ space group with parameters $a=4.305 \pm 0.001 \AA$, $c=3.706 \pm 0.01 \AA$.

The polycrystalline compounds were prepared from small size flakes of Ceylon natural graphite : the samples for static susceptibility measurements were sealed in a glass vessel and for the heat capacity study in a copper can. Starting from a small piece of Union Carbide pyrographite labelled "H.O.P.G. " a single crystal was prepared and sealed in a glass holder for E.P.R. measurements.
2. Experimental study. - 2.1 MAGNETIC MEASUREMENTS. - Static susceptibility measurements have been carried out with a standard Faraday balance. Because of the presence of some ferromagnetic impurities, introduced during the compound preparation in the high pressure cell, the magnetic susceptibilities reported in table I have been calculated from extrapolation of the magnetic force to infinite magnetic field. A quasi temperature-independent paramagnetism is found, which is about the same order of magnitude as in $\mathrm{C}_{8} \mathrm{M}$ compounds [6].

The E.P.R. investigation with a conventional $\mathrm{X}$ band spectrometer shows the existence of a Dysonian line defined by the ratio $A / B$ ( $A$ and $B$ are the heights of the two wings of the first derivative of the absorption line) [7]. This is characteristic of a charge carrier resonance which presents a small anisotropy of the $g$-factor and of the line width $\left(1 / \gamma T_{2}\right)$ (Table I).

2.2 Heat Capacity measurements. - They have been performed with an adiabatic calorimeter between 
TABLE I

\begin{tabular}{|c|c|c|c|}
\hline$T(\mathrm{~K})$ & & & \\
\hline $\begin{array}{l}\text { Experimental } \\
\text { values }\end{array}$ & 295 & 78 & 4.3 \\
\hline- & - & - & - \\
\hline st $\times 10^{6}$ & & & \\
\hline emu. GGS/mole & $53 \pm 5$ & $59 \pm 5$ & $63 \pm 5$ \\
\hline$A\{\mathbb{I}$ & $10 \pm 1$ & $15 \pm 1$ & \\
\hline $\bar{B}\{\perp$ & $10 \pm 1$ & $15 \pm 1$ & \\
\hline$\{\mathbb{l}$ & $2.0021 \pm 0.0005$ & $2.0021 \pm 0.0005$ & \\
\hline $9\{1$ & $2.0030 \pm 0.0005$ & $2.0030 \pm 0.0005$ & \\
\hline$\left(\frac{1}{\gamma T_{2}}\right)\{/ /$ & $0.800 \pm 0.025$ & $0.320 \pm 0.025$ & \\
\hline in gauss $(\perp$ & $0.570 \pm 0.025$ & $0.285 \pm 0.025$ & \\
\hline
\end{tabular}

1.5 and $4.5 \mathrm{~K}$. The heat capacity of the empty copper can mounted with a constantan wire heater and a germanium thermometer was measured in the first experiment (Fig. 1). The experimental points are fitted by using a least square method to the following relation :

$$
C=A T+B T^{3}+C T^{5}
$$

where $A, B$ and $C$ are parameters which are found to be in rough agreement with the standard values known for very pure copper.

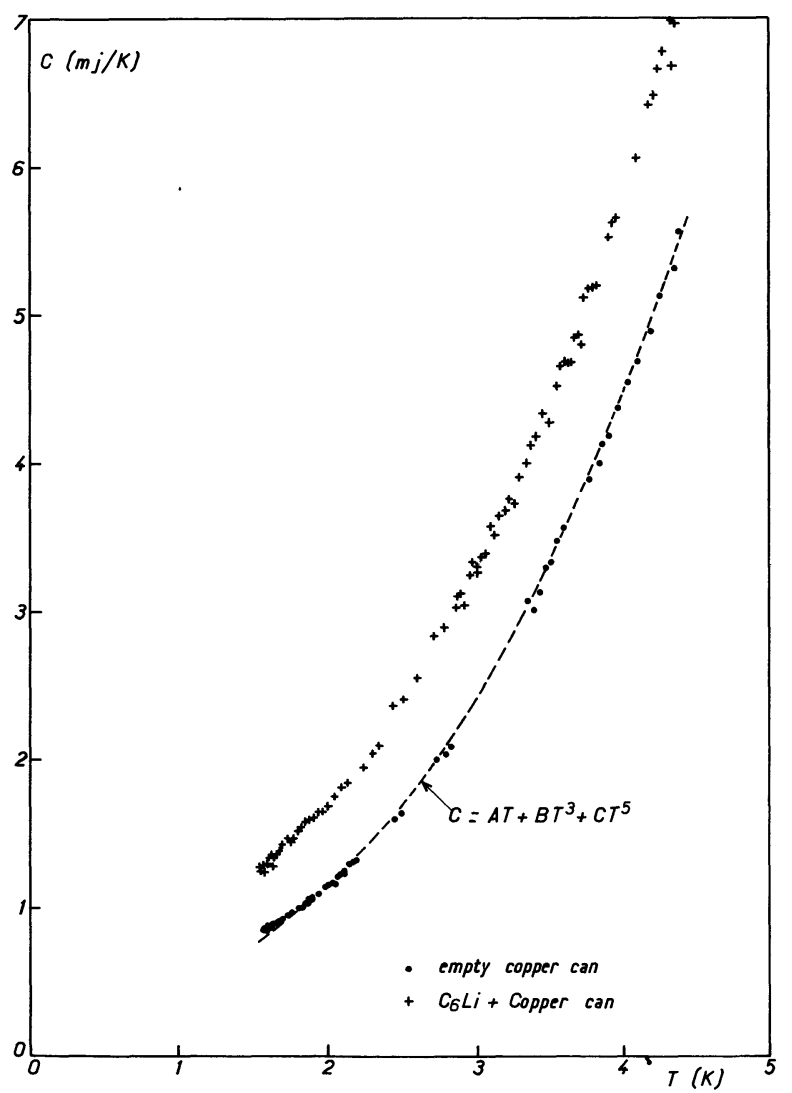

Fig. 1. - Heat capacity $K(\mathrm{~mJ} / \mathrm{K})$ versus temperature for the empty and full copper can in the $\mathrm{He}^{4}$ temperature range.
In the second run we filled up the copper can with a fine powder of Ceylon graphite in order to check the experimental set-up. The results are in agreement with the known values for natural graphite [8]. Then we have carried out the experiment with the lamellar compound $\mathrm{C}_{6} \mathrm{Li}$ introduced and pressed down under inert atmosphere in the cell (Fig. 1).

The specific heat $C_{\mathrm{p}}$ of $\mathrm{C}_{6} \mathrm{Li}$ has been calculated from the difference between experimental heat capacity values and eq. (1). The result (Fig. 2) shows that $C_{\mathrm{p}}$ is the sum of electronic and lattice contributions [9] :

$$
\frac{C_{\mathrm{p}}}{T}=a+b T^{2}
$$

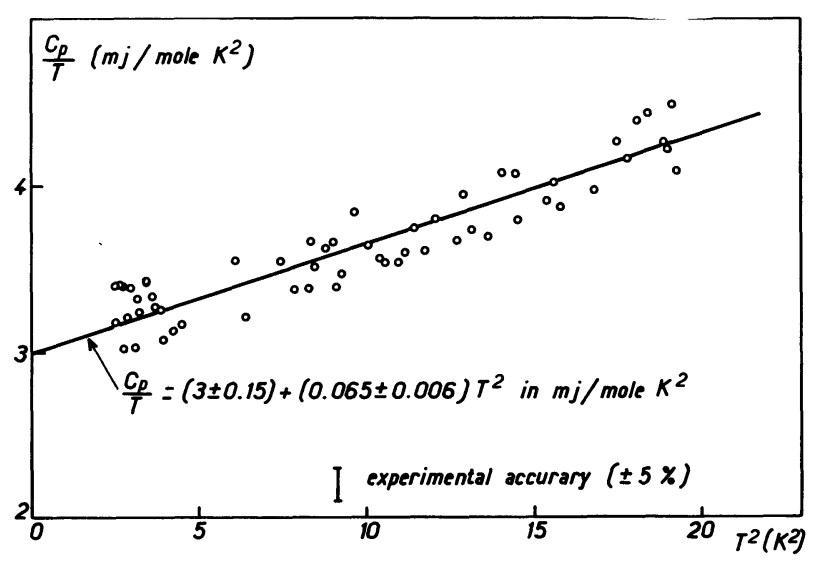

FIG. 2. - Specific heat $C_{\mathrm{p}}$ of $\mathrm{C}_{6} \mathrm{Li}$ plotted as $C_{\mathrm{p}} / T$ versus $T^{2}$.

The electronic term a allows us to calculate the density of electronic states at the Fermi level :

$$
N\left(E_{\mathrm{F}}\right)=1.27 \pm 0.06 \text { molecule }{ }^{-1} \mathrm{eV}^{-1}
$$

and the lattice term $b$ gives the Debye temperature for a three dimensional lattice : $\theta_{\mathrm{D}}=300 \pm 30 \mathrm{~K}$.

From $N\left(E_{\mathrm{F}}\right)$ it is straightforward to calculate the Pauli paramagnetism at zero Kelvin :

$$
\chi_{\mathrm{p}}=(41 \pm 4) 10^{-6} \text { uem CGS } / \text { mole } .
$$

This value is slightly smaller than the experimental one (Table I) : such a discrepancy may be due to the difficulty of preparing several grams (about $6 \mathrm{~g}$ for specific heat) of pure $\mathrm{C}_{6} \mathrm{Li}$ [5].

3. Analysis and discussion. - In order to propose an interpretation of these experimental data we can make two different assumphins regarding the electronic structure :

- There is charge transfer between lithium and graphite. The $\pi$ conduction band of graphite is filled up and each graphite plane is surrounded by diamagnetic $\mathrm{Li}^{+}$.

- There is metallic bonding between $\mathrm{Li}$ atoms which form a hexagonal structure that is apparently two dimensional. It is noteworthy that for metallic $\mathrm{Li}$ the hexagonal structure is the stable phase at very low temperatures [10]. 
If we now, compare these results with experimental data on metallic Li we find that the electronic specific heat term (for Li $a=1.63 \times 10^{-3} \mathrm{~mJ} /$ mole $\mathrm{K}^{2}$ ) [9] the spin paramagnetism $\left(\chi_{\mathrm{p}}=87.7 \times 10^{-6} \mathrm{emu} /\right.$ mole) [11], and the E.P.R. linewidth [12] which is different for other graphite lamellar compounds [3, 13], are qualitatively similar. Furthermore, the atomic radius is small enough to place $\mathrm{Li}$ atoms at the center of the aromatic rings, while this is not true for the other alkali metals [5]. We therefore think that the second model is essentially correct but a partial change transfer must exist because only the electropositive metals form lamellar compounds.

To confirm this hypothesis we, calculated the effective mass from the electronic specific heat term, we find for a two-dimensional electronic gas $m^{*} \simeq 5 m$, and for a three-dimensional electronic gas $m^{*} \simeq 3 \mathrm{~m}$.
From this result the two following remarks can be made :

- The Pauli paramagnetism is much larger than the Landau diamagnetism which may then be neglected in the static susceptibility measurements.

- The effective mass is larger than the usual values found for alkali metals.

In conclusion, from this first specific heat study on a graphite lamellar compound it seems that the graphite plays the role of a matrix and exerts a pressure on the lithium. This lamellar compound could become a superconductor under pressure but at a temperature below $1.5 \mathrm{~K}$ which is in a range that we have not yet explored. The electronic properties of graphite lamellar compounds are interesting and worthy of further investigation.

\section{References}

[1] Hannay, N. B., Geballe, T. H., Matthias, B. T., Andres, K., Schmid, P. and Macnair, D., Phys. Rev. Lett. 14 (1965) 225.

[2] Salzano, F. J. and Strongin, M., Phys. Rev. 153 (1967) 533.

[3] Poitrenaud, J., Revue Phys. Appl. 5 (1970) 275.

[4] Herold, A., Bull. Soc. Chim. France 187 (1955) 999. JUZA, R. and WeHLE, V., Natur. 52 (1965) 560.

[5] Guerard, D. and Herold, A., Carbon 13 (1975) 337.

[6] Furdin, G., Thèse Nancy (1974).

[7] Fehte, G. and Kip, A. F., Phys. Rev. 98 (1955) 337.
[8] De Sorbo, W. and Nichols, G. E., J. Phys. \& Chem. Solids 6 (1958) 352 .

[9] Kittel, C., Introduction to Solid State Physics 3rd Ed. (Wiley) 1967, p. 212.

[10] BarRetT, J., Acta Crystallogr. Danmark 9 (1956) 671.

[11] Kettler, J. E., Shanholtzer, W. L. and Vehse, W. E., J. Phys. Chem. Solids 30 (1969) 665.

[12] Watts, A. and Cousins, J. E., Phys. Status Solidi 30 (1968) 105.

[13] Muller, K. A. and Kleiner, R., Phys. Lett. 1 (1962) 98. 